\title{
Religion and literature: Critical reflections on reading the Bible, literature, theology and culture to $2000^{1}$
}

David Jasper

Faculty of Divinity

University of Glasgow

GLASGOW

Scotland

\begin{abstract}
Religion and literature: critical reflections on reading the Bible, literature, theology and culture to 2000

Despite its status as a "best-seller" for thousands of years, the Bible is rarely actually "read". It has been used by religious traditions for various purposes, primarily to maintain its status as authoritative text within their institutions. But if we return to the ancient midrashic tradition of reading and interpretation as opposed to more recent practices of biblical interpretation within the academies, we encounter a relentless exercise in reading the texts of Scripture, and a rediscovery of their strange, dangerous and often subversive powers. This is particularly important now as we face our "postmodern condition", in which what emerges as important is not the power of the centre, but the necessary revival of those on the margins and those whose voices have been stifled. Returning to these nervous practices of reading the Bible we find ourselves within the critical debates of postmodernity as it struggles with an apocalyptic sense of ending and beginning at the turn of the millenium.
\end{abstract}

\section{Introduction}

In this paper, I shall be concentrating to a very large extent upon the Bible, both the Hebrew Bible and the Christian Bible: a religious, cultural and literary resource for thousands of years; "a fountain of most pure water springing up

I Paper delivered at the conference on "Christianity and literature at the turn of the twentieth century" - Potchefstroom, August 1995. 
Religion and literature: Critical reflections on reading the Bible

into everlasting life"; 2 a cause of oppression; a supreme authority; a supreme scandal - above all, perhaps, the last: a scandal.

I am not particularly interested in the Bible "as literature", partly because the idea strikes me as decidedly redundant - of course the Bible is literature, even the remoter reaches of Leviticus; partly because the nineteenth century idea that one can "look at the Bible in the same way that one would look at any other book" 3 and then find that it is somehow different is strategically artificial and probably impossible, given the unique position of the Bible in our cultural history. There is, quite simply, nothing quite like it, for any number of reasons. What is quite remarkable about the Bible, as a runaway best-seller for these thousands of years, is how little it is actually read. Nor is this a recent phenomenon of our godless age given the general unavailability of the text to the mass reader until relatively recently. The experience of Offred, the handmaid, in Margaret Atwood's dystopic novel, The Handmaid's Tale (1985:98) is not untypical through the millenia of Judaeo-Christian culture.

The Bible is kept locked up, the way people once kept tea locked up, so the servants wouldn't steal it. It is an incendiary device; who knows what we'd make of it, if we ever got our hands on it? We can be read to from it, by him, but we cannot read.

Or again, at the end of Dostoevsky's Crime and Punishment (1866), as Raskolnikov lies imprisoned in Siberia:

Under his pillow lay the New Testament. He picked it up mechanically. The book belonged to Sonia; it was the same book from which she had read the raising of Lazarus to him ... He had never opened it till now.

He did not open it now, either, but one thought flashed through his mind: 'Is it possible that her convictions can be mine, too, now?' (Dostoevsky, 1970:558).

\section{The Bible as a text to get behind}

One does not read the Bible: what are of more importance are the convictions to which its authority gives rise. Typically, the Bible has been seen as a text to

2 Preface to the Authorized Version.

3 See for example Coleridge (1840), Jowett (1860) and most recently Gabel and Wheeler (1986). 
get behind. ${ }^{4}$ As Karl Barth (1975:125) categorically put it: "The Bible witnesses point beyond themselves". This has been so since ancient Jewish exegetical methods adhered to two basic hermeneutical strategies: first, to move beyond the literal meaning of the texts and integrate Scriptural interpretation into a larger theological framework; and second, to establish rules and conditions which will protect the community's identity and cohesion (see Jeanrond, 1991:15-17). The result of these strategies is that the Bible simply ceases to be "read", and when it is odd things tend to happen - even scandalous things. When John Milton "read" Genesis and produced Paradise Lost, his fellow poet Andrew Marvell was initially doubtful, fearing

That he would ruine (for I saw him strong)

The sacred Truths to Fable and old Song

("On Mr. Milton's Paradise Lost").

We see the danger of introducing Scripture into the intertextual world of literature. More recently, the critic Gabriel Josipovici found "reading" the Bible to be an odd and unexpected experience. It was not simply a question of reading the Bible "as literature": rather, he admits that he simply did not "know" the Bible in the way he knew (as a Professor of English) Chaucer, or Shakespeare, or Eliot.

And when I turned to it I found myself faced with two very striking things: the first was that this book, though supremely authoritative for Jews and Christians, did not, when one actually read it, appear anything like as authoritarian as the Aeneid or Paradise Lost. It seemed much quirkier, funnier, quieter than I expected. The second was that it contained narratives which seemed, even in translation, as I first read them, far fresher and more 'modem' that any of the prize-winning novels rolling off the presses (Josipovici, 1988:x) (my italics).

The Bible, in other words, is rather scandalous, or at least a bit risqué, if not for Josipovici quite the incendiary device feared in Margaret Atwood's novel. It is so because the institutions which have governed our digestion of the biblical canon bave carefully excluded its radical irony and its profound resistance to the distinction between sacred and secular (see Bloom, 1989), qualities which it possesses in abundance, and shares with other great literature. Thus to read, in our own time, the novels and parables of Franz Kafka, with all their irony, slippages and uncertainties, is to experience something of their "appallingly

4 See John Barton (1988:59): "So far I have necessarily concentrated on how essential it is to see the Bible as a text which we can get behind ...". 
Religion and literature: Critical reflections on reading the Bible

violent tradings with the Jewish Scripture" - and to be shocked into a recognition of the deep resistance of Scripture to the conclusive tendencies of our interpretations and hermeneutics.

\section{The dismissal of the textuality of the Bible}

If we go back to a relatively early date in the Christian interpretation of the Bible, to Augustine's first readings in Scripture, we find a tension which subsequent Christian hermeneutic practice has fairly successfully dampened down in the interest of good order. Before he became a Christian, Augustine had been trained as a classical rhetorician, skilled in classical literary devices and style. Initially he is utterly dismissive of the style of the Scriptures. "To me they seemed quite unworthy of comparison with the stately prose of Cicero, because I had too much conceit to accept their simplicity and not enough insight to penetrate their depths" (Augustine, Confessions, III; also see Norton, 1993:4-5). This dismissal of the textuality of the Bible is crucial, and has been disastrous in Christian history. The Bible is the repository of divine mysteries, yet a book hardly worth reading except through the mediation of the theologians and ordained authorities of the church, who purvey, for us, its

"sacred truths" shorn of the dangers of its "rough" textuality.

But the Bible, as Josipovici asserts, can be as modern and as exciting as any contemporary work of fiction - indeed, D.H. Lawrence once described it as "a great confused novel" (Lawrence, 1967:107-108). One might say that the history of biblical hermeneutics, both Jewish and Christian, has been a series of strategic attempts to subdue the scandalous tendencies of canonical Scripture and thereby to disable interpreters from actually reading the Bible. I sometimes remark, when feeling particularly tetchy about my colleagues, that professional biblical critics - not to speak of the clergy - are in the business of actually preventing us from reading the Bible, that is, of establishing various hermeneutical strategies (for example, "form criticism", "redaction criticism" and so on), which yield certain results in a more or less precalculated way and sometimes almost in spite of the text itself. From Augustine we have seen that getting behind the text has been the primary purpose of biblical interpreters, encouraged linguistically by the Bible's character as a translated book.

\section{The Bible as a translation of translations}

That is, it is not simply we who encounter the Bible in translation into English. It has always been translated - the Hebrew of the Jewish Bible frequently

5 See Cunningham (1994:386); Robbins (1991) - on "Kafka's Parables" (chapter 3). 
David Jasper

rendered from an earlier Canaanite, Mesopotamian or Epyptian text, for example (for a fuller discussion, see Prickett, 1993:4-20). The synagogues in Jesus' times read the Hebrew scriptures in the Aramaic translations and paraphrases called Targums or else the Greek Septuagint. The New Testament itself was never written in Jesus' own language (which was, probably Aramaic), but a debased form of Greek known as Koine. In other words, what we have now are translations of translations, occasionally offered in a vernacular (by Reformers like Martin Luther), but always accessible only through interpretation and the media of "knowledgeable" authorities. Most modern English translations are prefaced by either a claim for their authoritative status within the Christian churches, or an assurance that they are accompanied by a sufficient critical apparatus to enable the "ordinary reader" (a term used in the Jerusalem Bible of 1968) to understand what is being said. ${ }^{6}$

These precautions are not peculiar to Christianity. In the apocryphal II Esdras (problably late first century CE), God dictates ninety-four books to the priest and prophetic scribe Ezra, concluding with the words: "Make public the books you wrote first, to be read by good and bad alike. But the last seventy books are to be kept back, and given to none but the wise among your people" (II Esdras $14: 45-46$ ). So here again in Israel the common reader is "protected" - read to through the interpretative procedures of the wise among the people. Scripture has always been literature with a purpose - to instruct or to offer salvation ${ }^{7}$ never "simply" literary like Shakespeare or Wordsworth: So Samuel Johnson (quoted in Fisch, 1990:1) taught that "the intercourse between God and the human soul cannot be poetical", and in our own century, T.S. Eliot (1951:390) affirmed that "the fact that men of letters now discuss it [the Bible] as 'literature' probably indicates the end of its literary influence".

6 The Preface to the Revised Standard Version (1973:iii-iv) states that this Bible is "an authorized revision of the American Standard Version of 1901 ". Alexander Jones in his Editor's Foreword to the Jerusalem Bible (1968:v), remarks that "the brief Introduction and Notes are here only to help the ordinary reader to understand what he is reading ...". The Preface of the Good News Bible (1976) "explains the nature of the special aids for readers which are included in the volume". One could go on almost ad infinitum.

7 So for example, the Foreword to the Good News Bihle expresses a trust that people will find in this translation "a saving hope through faith in God who made possible this message of Good News for all people". For a Jewish perspective, see Fisch (1990)

Koers 61(1) 1996:21-36 
Religion and literature: Critical reflections on reading the Bible

\section{Strategies to ensure the authority of the Bible}

These interpretative strategies exercised upon the books of the Bible ensure the promotion ol an authority and power which is not intrinsic to the texts themselves. Rather their power is embedded in historical situations structured to guarantee (and be guaranteed by) just this authority. ${ }^{8}$ Thus, it is no accident that biblical criticism as we have inherited it over the past two hundred years or so has been firmly established on historical principles, since Johann Gottfried Eichhorn (1752-1827) coined the term Higher Criticism (die höhere Kritik). In his Enleitung ins Alte Testament (1780-1783), Eichhorn develops the theory that the sacred literature of Israel was a product of human ingenuity developed through various shapes of barbarism and semi-civilisation: at the same time he sees the Old Testament as the expression of divinely inspired ideas. In other words, with his interest in the ideas rather than the text, his position is more or less that of St. Augustine of Hippo, and Eichhorn is far more concerned with studying the origin, context, significance, development and reception of the Bible than actually reading the texts themselves.

When, in 1827, the English poet and scholar S.T. Coleridge begins a systematic reading of Eichhorn's work he constantly criticizes his failure to respond to the poetic power of the texts of Scripture, his classical preference for the literature of Greece and Rome and his obsession with the history of biblical reception. Coleridge (1984:480) attributed to the influence of "the German Mind and character" that

... to think \& speak of the Jews and of the Hebrew Writers as a poor, barbarous unenlightened Set, when it was the absurdity of superstitious prejudice to compare otherwise than by contrast with the Legislators, Philosophers, Poets \& Historians of Greece and Rome, had become the indispensable Mark and Criterion of a liberal and enlightened Person.

This prejudice towards so-called "Hellenism" as opposed to a semi-barbarous "Hebraism" became a commonplace in the nineteenth century", and sub-

8 See further, Gerald Bruns (1984:462-480): “... the power of the text is not intrinsic to it. On the contrary, the text draws its power from the situation which belongs to a definite history and which is structured by this history to receive just this text as it will no other" (Bruns, 1984:466).

9 See, most importantly, Matthew Amold Culture and Anarchy (1869:130): "Hebraism and Hellenism, - between these two points of influence moves our world. At one time it feels more powerfully the attraction of one of them, at another time of the other; and it ought to be, though it never is, evenly and happily balanced between them." 
stantially in biblical studies still: and however much Eichhorn, and later Schleiermacher, might protest that their hermeneutics and modes of enquiry applied equally to sacred and "secular" literature, yet in practice they confirmed the particularity of the text of biblical interpretation ${ }^{10}$, and carefully isolated the authoritative texts, confirming their status not as literature to be read but as documents affirming theology and a historical tradition. Their treasures lie within earthen vessels which are actually odder, quirkier, arguably less "authoritative" (in the sense required by the custodians of the faith) than is comfortable for these hermeneuts.

What, then, of the other "tradition" in biblical interpretation, the much older tradition of Jewish hermeneutics, established long before Augustine first read the Bible? Modern critics have not been slow to point at the "theological spectres" which haunt contemporary literary criticism, and equally ready to affirm the central place in our current explorations in reading and textuality of what Susan Handelman (1982:xv) has called "Rabbinic modes of interpretation." I Not, of course, that Jewish hermeneutics are not profoundly concemed with questions of authority. For the Scriptures contain the Torah, that is the divinely given order of life, and the divinely inspired account of Israel's relationship with Yahweh: the words of the Torah are, indeed, God's own words (see further Jeanrond, 1975:15ff; Longenecker, 1975.). Deeply responsive to the spiritual and cultural requirements of Israel, Jewish hermeneutics nevertheless are characterized by a mode of interpretation known as the Midrashic, a term of immensely complex significance ${ }^{12}$ but informed by one overriding notion, that is a genuine concern for text, or more precisely, "intertextuality". The Israeli critic Daniel Boyarin (1990:12) usefully summarizes this term, so widespread in modern critical terminology.

This concept has several different accepted senses, three of which are important in my account of midrash. The first is that the text is always made up of a mosaic of conscious and unconscious citation of earlier discourse. The second is that lext may be dialogical in nature - contesting their own assertions is an essential part of the structure of their discourse - and that the

10 "Do the Holy Scripture, by virtue of their special nature, also require a special hermeneutics? Yes. But a special hermeneutics can be understood only in terms of general hermeneutics; otherwise, the result is still an aggregate" (Schleiermacher, 1986:67).

11 Also see Handelman $(1982 ; 1991)$ and Cunningham (1994:363-410).

12 For a useful and accessible introductory account see Jacob Neusner (1987). 
Religion and literature: Critical reflections on reading the Bible

Bible is a preeminent example of such a text. The third is that there are cultural codes, again either conscious or unconscious, which both constrain and allow the production (not creation) of new texts within the culture; these codes may be identified with the ideology of the culture, which is made up of the assumptions that people in the culture automatically make about what may or may not be true and possible, about what is natural in nature and in history. ${ }^{13}$

While remaining clearly within a historical consciousness, these assertions nevertheless have three important consequences in our present conversation. First, they exclude the romantic notion that literary creation is original and $e x$ nihilo: rather, texts are in continual and necessary dialogue with one another, contradicting any literary isolation artifically imposed upon the Bible. Second, they deny any establishment of what has been termed the "glacial-moraine" (gletscherwall) ${ }^{14}$ which the academic world built in the nineteenth century between biblical studies and the study of other literatures in the "humanities". Third, they reintroduce the necessity of the reading of and between biblical texts, a practice, as we have seen, little encouraged by the formal institutions of the Judaeo-Christian tradition.

\section{Midrash: a relentless exercise in reading the text}

In midrashic reading the text becomes a place of struggle, a fertile and often mysterious ground endlessly productive of energetic readings and re-readings, commentaries that become intertexts. Thus, in midrashic readings of the mysterious episode of the wrestling Jacob (Genesis 32:1-22), Genesis Rabbah quotes Rabbi Berekiah:

There is none like God (Deut. 32:26); yet who is like God? Jeshurun, which means Israel the Patriarch. Just as it is written of God, And the Lord alone shall be exalted (Isaih 2:11), so of Jacob too: And Jacob was left alone (Genesis 32:25) (Freedman \& Simon, 1961:710). ${ }^{15}$

The extraordinary identification of Jacob with Jeshurun is underwritten by the prooftext, Deuteronomy 32:26. Jacob is "alone" in two senses; left on his own,

13 Boyarin's comments are well illustrated by the writings of the Jewish critic Harold Bloom from The Anxiety of Influence (1973) through a series of more recent books.

14 The term "glacial-moraine" is from Herman Usener, discussed by Stephen Prickett (1986:1ff).

15 I am also drawing here upon the fine essay by Geoffrey $\mathrm{H}$. Hartman, "The struggle for the text" (Hartman \& Budick, 1986:3-18). 
David Jasper

and, like God, solitary singular. In other words, as Jacob wrestles with God, so God wrestles with Himself.

Midrash continues to play - or wrestle - daringly with difficult words. Genesis 32:28 - "You strove with God [Midrash: Angels - elohim] and with men", which might refer to Jacob's previous difficulties with Esau and Laban, or may be read as a hendiadys - something like "with godlike men", or even, "a godlike man". In the recent Torah Commentary (Union of American Hebrew Congregations, New York, 1981), the name Yisrael is hardly explained, but instead complicated (see Plant et al., 1981), derived, it is suggested, from yashar-el (the one whom God makes straight), rather than yaakov-el (the one whom God causes to limp). The change of name, in any case, denotes a change of character, the being of God with Jacob (as promised reassuringly in Genesis 28:15) seen here as a dangerous conflict, the flaw in Jacob's character being replaced by the divinely inflicted wound. Thus Sigmund Freud (1955:64) concludes in Beyond the Pleasure Principle with the hardly scientific conment, "It is no sin to limp" (see also Hartman, 1986:8; Cunningham, 1992:303-309).

What this midrashic excursus illustrates is not only the daring of such rabbinic reading, but as a reminder, in Hartman's (1986:9) words, that

... little is more important today than to remind secular literary [and, one might add, academic biblical] studies of the richness and subtlety of those strange rabbinic conversations which have been disdained for so long in favor of more objective and systematized modes of reading. Moreover, for any text to remain alive requires the attention and supplementation of commentary. But this sets up a paradox involving the relation of source-text to the concept literature.

What strikes one about midrash is its close and undiverted attention to the difficulties of the text, that is, its literary attentiveness. It does not dive behind the text seeking historical explanation or solution. Instead, it engages in a relentless exercise in reading which becomes itself a creative text, deeply almost accidentally - theological, and daring, quite boldly, to be wrong. Daring, in other words, to risk its authority as definite, objective and systematic.

I do not wish to claim too much here. I am simply looking for clues and for ways of understanding both the immense and lasting influence of the Bible on Western literature, and the strange way in which it is returning, by an odd and enexpected route, to the agenda of literary and cultural studies at the end of our own God-forsaken century. Its influence on Westem literature has been, of course, through the cultural and spiritual power of religion tradition, but, much more significantly, I think, through its insistent, unacknowledged scandal and 
Religion and literature: Critical reflections on reading the Bible

difficulty - the ambiguity and multiple suggestiveness of its texts which refuse, ultimately, to be tamed by hermeneutical orthodoxy. This is what we might call the "counter-poem" 16 of the Bible with which the midrashist struggles, and which edgily inspires poets from Milton and Marvell, to Blake and to Hopkins.

\section{The Bible: occupying merely an iconic position at the centre of a lost tradition?}

The Bible returns now as, having lost our critical confidence in the authority of the text in a century littered with the critical fallacies of intention, reference and so on, we have begun again to take the business of reading seriously. Thinking back to our scholarly guides in the field of literature and religion some decades ago, I am struck now by first, what poor readers many of them were, and, second, how concerned they were to maintain a sense of the authority of the text, and above all, the text of the Bible. However much we owe, for example, to Northrop Frye, one must suspect that he was, finally, more interested in system than readerly struggle, and his attitude to Scripture remained devoutly unyielding. In The Secular Scripture (Frye, 1976:7), for example, he affirmed:

In European literature, down to the last couple of centuries, the myths of the Bible have formed a special category, as a body of stories with a distinctive authority. Poets who attach themselves to this central mythical area, like Dante or Milton, have been thought of as possessing a special kind of seriousness conferred on them by their subject matter.

I am simply not convinced by this. I suspect that Frye's understanding of the nature of biblical authority has more to do with the power of the Christian tradition which uses the Bible than with the "stories" themselves, and that Dante and Milton remain as serious poets because they wrote serious poetry, not because they attached themseives to "the central mythical area". Many writers, after all, who have concerned themselves with biblical matter are no longer taken seriously at all. Indeed, thus to privilege great writers, to protect them with the sanctity of eternal truths and sterile prejudices, is ultimately to commit them to a literary canon where they remain venerated and largely unread (I think of struggling to persuade students actually to read Paradise Lost) - like the Bible itself, and, as Terry Eagleton (1983:217) has put it, the liberation of great writings "from such controls may well entail the death of literature, but it may also be their redemption".

16 See Daiches (1984:32) for a discussion of the term "counter-poem" in the context of Paradise Lost. 
What, then, of the Bible as we approach the end (and beginning) of another millenium? For more than two decades, now, we have grown accustomed to thinking of the culture of "postmodernity", accustomed, almost to surviving within the crisis of legitimation ${ }^{17}$, authority and responsibility, so much so that we have, perhaps, become dulled to the enormity of the aporetic task of actually thinking the possibility of impossibility (see Derrida, 1993:72). More precisely, in a century sickened by death and genocide, we are farther than ever from acknowledging that our one common, unavoidable experience, death - my death - can never be subject to an experience that would properly be mine, that is, accountable and personal. The most real is at the same time the most distant. We are left with the magnificent inconclusive and unconcluded ending (which is no ending as the opera was never completed) of Arnold Schoenberg's extraordinary Moses und Aaron (1932) when Moses bewails his inarticulacy in comparison with his elegantly lyrical brother Aaron: "O Wort, du Word, das mir fehlt!" ("O word, thou word that I lack!"). Moses' cry echoes the persistent lament of our own post-Romanticism - that we live within no sustaining tradition and also without the Romantic faith in the self-sufficiency of human subjectivity.

Furthermore, since we have never read the Bible, which occupies merely an iconic position at the centre of a lost tradition we have no means to recover its energies and its possibilities of liberation. Or, is the sense that things of real significance are now not at the centre but on the ragged edges and boundaries of our uncertainties of some importance? Perhaps the most consistent critical shift in literary studies over the past few decades has been in the reappraisal and investigation of the reading process, so-called reader-response criticism. ${ }^{18}$ Whatever this means, in its many and various forms, it at least indicates a recovery of a sense of the responsiblility of the reader and the reader's task. Could this mean a renewed freedom to return again to the profound scandal of the Bible? At least one critic, Valentine Cunningham (1994:371) goes so far as to suggest that

... the postmodernist scene comprises a kind of vast post-Biblical J-text, or set of J-texts, written (of course!) by writers with names like James Joyce, son of John Joyce, Jacques Derrida, Jacques Lacan, Edmond Jabès, Jehovah,

17 See Lyotard (1986:8-9): “... knowledge and power are simply two sides of the same question what decides what knowledge is, and who knows what needs to be decided?"

18 For a useful summary, see the collection edited by Tompkins (1980). 
Religion and literature: Critical reflections on reading the Bible

Joseph, Job, Jeremiah, Jonah, and haunted not least by the J-text(s) and the so-called J-author of the Old Testament. 19

If there is an identifiable reason for this, I suggest it may lie in the final refusal of Matthew Arnold's desire to reconcile (in a vague talk of "balancing") the differences and oppositions between the "Hellenistic" (classical) and the "Hebraic" (Judaeo-Christian), but rather to live with the violence of all opposition and contradiction. Finally overthrowing the last vestiges of our persistent Hegelianism, we may be led by Derrida, after Emmanuel Levinas, to "think the limits" (cf. Norris, 1987:230-231) of thought and experience (even beyond them to our one great common experience) and to abandon the dream, which has become the nightmare of the twentieth century, of a single, comprehensive vision. On the edge, dangerously and nervously, we encounter the contamination and necessary evil of writing (see Derrida, 1967 on Rousseau) - the evil of writing which forces us again to read, for our very lives, and discover there the possiblility of death. Derrida (1989:62) has suggested:

Perhaps there would be no prayer, no pure possibility of prayer, without what we glimpse as a menace or as a contamination: writing, the code, repetition, analogy or the - at least apparent - multiplicity of addresses, initiation. If there were a purely pure experience of prayer, would one need religion and affirmative or negative theologies? Would one need a supplement of prayer? But if there were no supplement, if quotation did not bend prayer, if prayer did not bend, if it did not submit to writing, would a theiology be possible? Would a theology be possible?

"To submit to writing": to suffer again the impurities and uncertainties of reading a collection of texts, the Bible, which have scoured, irritated, scandalized and provoked our literature like no other text, in spite of the cordon sanitaire of sacrality persistently laid around them.

\section{Reading the Bible again: the realization of the theological roots of literary practice}

The Bible, so much of which is cast in the face of disaster, the unthinkable and the unknowable, has rarely been more alive than today, in spite of the protests of the academy of biblical scholars and churchpeople. In the hands of the outsiders, those on the edges, the sinners, feminists, liberationists and the

19 This reference is of course to Harold Bloom's The Book of J. (1990), after the socalled "narrative sources" of the Pentateuch, J. (Jahwist), E (Elohist), D (Deuteronomist) and P (Priestly). 
David Jasper

godless, we find the Bible read again. In the apocalyptic chapter 13 of Mark's

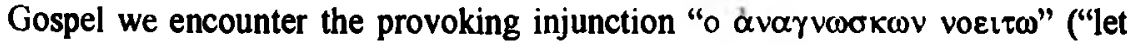
the one who reads understand"). It is almost a tautology in the Greek - "let the one who discerns understand". To read is to discern. But how do we catch the tone here? Is this a shrug of the shoulders - "make of this what you will"? Is it a knowing wink - "you know what I mean"?

To read is to discern: that is, not to be certain, but to enter into the density of the writing and to experience it as the incendiary device which Mark's Gospel undoubtedly is.

For some time now, those involved in the academic world of literary studies have been involved in a huge debate, an argument centred upon a complex and ill-defined word, theory. It is a debate which divides so-called "theorists" from "non-theorists", and which has spawned a multitude of self-righteous attitudes and "-isms", some politically driven, others socially motivated, some just plain silly. Quite possibly all that this upheaval indicates is that the study of literature is growing, stammeringly, into a degree of self-consciousness which before it has patently lacked. Furthermore, as some people now suggest that the great day of theoretical debate are behind us (probably meaning that the brilliant articulacy of the 1980s has been replaced by a much more confused incoherence and refusal to accept responsibilities), what is increasingly emerging is an unwilling - for most people - realization of the theological roots of our literary practice and undertaking. The "gletscherwall" is melting, not by anyone's design, and certainly not as a result of any evangelistic resurgence of the traditional powers of our religious and theological traditions. It is melting because of a crisis.

A recent working party report - 'English: A common concem' (1994) - on the future of English Studies in Great Britain stated:

Theory is a name for what 'English' can't accommodate: or used not to be able to. The crisis may be ending, and I hope it is, but it hasn't ended yet (Wood, 1994).

But the crisis is not ending, and will not. For it is the krisis of which Karl Barth was writing in the 1920 's, a crisis only to be seen as apocalyptic. "Let the reader understand." Perhaps the true crisis of postmodernity may be that we find ourselves doing something which we have never done before in a wrestling which both maims and heals - that is reading the Bible. 
Religion and literature: Critical reflections on reading the Bible

\section{Bibliography}

ARNOLD, Matthew. 1869. Culture and anarchy. Cambridge : Cambridge U.P.

ATWOOD, Margaret. 1985. The handmaids tale. London : Virago Press.

AUGUSTINE. Confessions. Book III.5. Trans. R.S. Pine-Coffin. Harmondsworth : Penguin. 1973.

BARTH, K. 1975. Church dogmatics. 1/1. Edinburgh : T. \& T. Clark.

BARTON, John. 1988. People of the Book? The authority of the Bible in Christianity. London : S.P.C.K.

BLOOM, Harold. 1989. Ruin the sacred truths. Cambridge Mass. : Harvard U.P.

BLOOM, Harold. 1990. The book of J. London : Faber \& Faber.

BRUNS, Gerald. 1984. Canon and power in Hebrew scriptures. Critical Inquiry, 10(3):462-480.

COLERIDGE, S.T. 1840. Confessions of an inquiring spirit. Menston : Scolar.

COLERIDGE, S.T. 1984. Marginalia II. (Ed. Whalley, George. Collected Coleridge vol. 12(2). Princeton : Princeton U.P. p. 480.)

CUNNINGHAM, Valentine. 1994. In the reading Gaol: Postmodernity, texts and history. Oxford : Blackwell.

DAICHES, David. 1984. God and the poets. Oxford : Oxford U.P.

DERRIDA, Jacques. 1976 [1967]. Of grammatology. Trans. Gayatri Chakravorty Spivak. Baltimore : John Hopkins U.P.

DERRIDA, Jacques. 1989. How to avoid speaking: Denials. (In Iser, Wolfgang \& Budick, Sanford eds. Languages and the unsayable. New York : Columbia U.P. p. 3-70.)

DERRIDA, Jacques. 1993. Aporias. Trans. Thomas Dutoit. Stanford : Stanford U.P.

DOSTOEVSKY, Fyodor. 1970 [1866]. Crime and punishment. Transl. by David Magarshack. Harmondsworth : Penguin.

EAGLETON, Terry. Literary theory: An introduction. Oxford : Blackwell.

ELIOT, T.S. 1951. Religion and literature. (In Selected Essays. 3rd edition. London : Faber \& Faber. p. 388-401.)

FISCH, Harold. 1990. Poetry with a purpose: Biblical poetics and interpretation. Bloomington : Indiana U.P.

FREEDMAN, Harry \& SIMON, Maurice. ed. 1961. Genesis Rabbah. Vol. 1 of Midrash Rabbah. London : Soncino Press.

FREUD, Sigmund. 1955. Beyond the pleasure principle. (In Freud, S. Complete Psychological works. Vol. 18. Trans. James Strachey. London : Hogarth Press. 
FRYE, Northrop. 1976. The secular scripture: A study of the structure of romance. Cambridge Mass. : Harvard U.P.

GABEL, John B. \& WHEELER, Charles B. 1986. The Bible as literature: An introduction. Oxford : Oxford University Press.

HANDELMAN, Susan. 1982. The slayers of Moses: The emergence of rabbinic interpretation in modern literary theory. Albany : State University of New York Press.

HANDELMAN, Susan. 1991. Fragments of redemption. Bloomington : Indiana U.P.

HARTMAN, Geoffrey H. \& BUDICK, Sanford. eds. 1986. Midrash and literature. New Haven \& London : Yale U.P.

JEANROND, Wemer, J. 1991. Theological hermeneutics: Development and significance. Basingstoke : Macmillan.

JOSIPOVICI, Gabriel. 1988. The Book of God: A response to the Bible. New Haven : Yale U.P

JOWETT, Benjamin. 1860. The interpretation of Scripture. (In Essays and reviews. London : s.n. p. 400 ff.)

LAWRENCE, D.H. 1967. Why the novel matters. (In Beal, Anthony ed. Lawrence. Selected literary criticism. London : Heinemann. p. 102-108.)

LONGENECKER, Richard N. 1975. Biblical exegesis in the apostolic period. Grand Rapids : Eerdmans.

LYOTARD, J.-F. 1986. The postmodern condition. Trans. Geoff Bennington \& Brian Massumi. Manchester : Manchester U.P.

NEUSNER, Jacob. 1987. What is Midrash? Philadelphia : Fortress Press.

NORTON, David. 1993. A history of the Bible as literature. Vol. 1. Cambridge : Cambridge U.P.

PLANT, W.G., AMBERGER, B.J. \& HALLO, W. eds. 1981. The Torah: A modern commentary. New York : Union of American Hebrew Congregations.

PRICKETT, Stephen. 1986. Words and "The Word". Cambridge : Cambridge.

PRICKETT, Stephen. 1993. The changing of the host: Translation and linguistic history. (In Jasper, David. Translating religious texts. Basingstoke : Macmillan. p. 4-20.)

ROBBINS, Jill. 1991. Prodigal son / elder brother. Chicago : Chicago U.P.

SCHLEIERMACHER, F.D.E. 1986. Hermeneutics: The handwritten manuscripts. $E d$. Heinz Kommarte. Atlanta : Scholars Press.

TOMPKINS, Jane P. 1980. Reader-response criticism: From Formalism to post-Structuralism. Baltimore : John Hopkins University Press. 
Religion and literature: Critical reflections on reading the Bible

WOOD, Michael. 1994. "Introductory talk on English: A common concem."

York Seminar Report on English in the 21st century. NATE Cross Phase

Working Party. 